Article

\title{
Evaluating Relations between Originality, Efficiency, Conformism and Entrepreneurial Potential of Students in a Fast Changing Business Environment
}

\author{
Mia Maric ${ }^{1}$, Mladen Subotic ${ }^{1, *}$, Branislav Dudic ${ }^{2,3, *}$,, Boban Melovic ${ }^{4}$, Natasa Brankovic ${ }^{1}$ \\ and Stevan Milisavljevic ${ }^{5}$ \\ 1 Faculty of Education in Sombor, University of Novi Sad, 25000 Sombor, Serbia; \\ mia.maric@pef.uns.ac.rs (M.M.); natasa.brankovic@pef.uns.ac.rs (N.B.) \\ 2 Faculty of Management, Comenius University in Bratislava, 82005 Bratislava, Slovakia \\ 3 Faculty of Economics and Engineering Management, University Business Academy, 21000 Novi Sad, Serbia \\ 4 Faculty of Economics, University of Montenegro, 81000 Podgorica, Montenegro; bobanm@ac.me \\ 5 Faculty of Technical Sciences, University of Novi Sad, 21000 Novi Sad, Serbia; steva@uns.ac.rs \\ * Correspondence: mladen.subotic@pef.uns.ac.rs (M.S.); branislav.dudic@fm.uniba.sk (B.D.)
}

check for

updates

Citation: Maric, M.; Subotic, M.; Dudic, B.; Melovic, B.; Brankovic, N.; Milisavljevic, S. Evaluating Relations between Originality, Efficiency, Conformism and Entrepreneurial Potential of Students in a Fast Changing Business Environment. Sustainability 2021, 13, 1593. https://doi.org/10.3390/ su13041593

Academic Editor:

Constantin Bratianu

Received: 29 November 2020

Accepted: 29 January 2021

Published: 3 February 2021

Publisher's Note: MDPI stays neutral with regard to jurisdictional claims in published maps and institutional affiliations.

Copyright: (c) 2021 by the authors. Licensee MDPI, Basel, Switzerland. This article is an open access article distributed under the terms and conditions of the Creative Commons Attribution (CC BY) license (https:/ / creativecommons.org/licenses/by/ $4.0 /)$.
Abstract: The purpose of this paper is to evaluate the relations of originality, efficiency, conformism, and entrepreneurial potential. The sample consisted of a student population from Serbia and Bosnia and Herzegovina as EU candidate countries and from the EU member country, Belgium. Research results can help policy makers receive valuable information on how to improve student attitude towards entrepreneurship. Data was collected from a sample of 1008 university students from these three countries. The Kirton Adaptation Innovation Inventory (KAI), Questionnaire on Entrepreneurial Traits (QET), and The Scale of Entrepreneurial Potential (SEP) were applied in the research in order to obtain data. Canonical correlation analysis revealed a significantly strong relation between originality, efficiency, conformism, and dimensions of the Entrepreneurial Traits model, as well as significant relation to the entrepreneurial potential model. Findings from this study may provide data that could be used to develop and foster the entrepreneurship potential of students and help improve the economy in the region.

Keywords: KAI model; entrepreneurship; entrepreneurial potential; students; originality; efficiency; conformism; student's attitude; kirton adaptation-innovation inventory; questionnaire on entrepreneurial traits; the scale of entrepreneurial potential

\section{Introduction}

Previous studies concentrated on researching personality traits [1-4] found connections between personal traits and entrepreneurship while some research in this field showed inconclusive results [5]. Among the personal traits that implicate a significant relation with entrepreneurship, Yan [4] found proactivity which drives individuals to create opportunities and improve. Rauch and Frese [3] concluded in their research that studies should take into account personal traits and their influence on entrepreneurship if improvement in this field of study was to be made.

Entrepreneurship has been in the center of focus of educators and policy makers for the past decades. This is because economic development is largely a consequence of entrepreneurs who by implementing their creativity and innovativeness create new businesses [6]. "Innovation is the successful implementation of creative ideas by an organization" [7]. Innovativeness is considered to be one of the tools of entrepreneurship [8]. Studies of Hult et al. [9] also show that entrepreneurial potential and orientation are in significant correlation with innovativeness. Goldsmith and Kerr [10] concluded in their study that Kirton's view of an innovative style of problem solving is significantly related to better comprehension of entrepreneur's behavior. Engl et al. [11] in their research 
come to the conclusion that KAI can be used as a useful instrument for recognizing potential entrepreneurs.

Contemporary research has linked the importance of entrepreneurial curricula in education system design to the formation of a society's ability to nurture and support entrepreneurial development. While many countries have begun to include entrepreneurship in national education plans, it is important to appreciate the cultural, social, economic, and political organization and how they may impact entrepreneurial skills, knowledge, and behavior. In this paper using the KAI model, we review entrepreneurship traits, in one EU and two post socialist states, and show the relevance of the model for a post socialist context.

\subsection{Economic and Entrepreneurship in Post Socialist States}

Global Entrepreneurship Monitor (GEM) 2019/2020 clearly points out the problems countries like Bosnia and Herzegovina and Serbia face in their post-socialist transition. Moreover, such societies had a pause in entrepreneurial mindset for over 50 years. Lack of an entrepreneurial role model among family members or in the near surrounding negatively influences the development of entrepreneurial activity [12]. In its report, GEM (2019/2020) acknowledges the cultural context and the political heritage as important factors that form a structure that positively or negatively influence the development of entrepreneurship in transitional countries where entrepreneurial activity is seen as a new characteristic due to their socialist burden.

The similarity between these two countries not only lies in the fact that both countries are EU candidates, but it is also embedded in their shared history. Both countries were part of former Yugoslavia and had carried the socialist heritage with the same educational system and the very troubling transition to capitalism shaded by corruption [13]. We observed that entrepreneurial activity is very slowly rising in these two neighboring countries and we focused on studying student entrepreneurial potential by evaluating relations of originality, efficiency, and conformism subscales of the KAI model.

\subsection{Entrepreneurship Education and Post Socialist States}

Lack of entrepreneurship in Serbia and Bosnia may be explained as a post socialist burden on society; also there are not enough studies researching entrepreneurship which leads to lack of knowledge and becomes an obstacle in better understanding of the phenomenon. The student population represents the country's most valuable human resource keeping in mind that they become the most educated part of the population. The policy implications of the Global Entrepreneurship Monitor [14]; Ruda et al. [15] point that education is crucial for the development of entrepreneurial activity, people with poor education are less likely to engage in any kind of entrepreneurship activities. Lingelbach [16] recently indicated: "Entrepreneurship in developing countries is arguably the least studied significant economic and social phenomenon in the world today". They outline the necessity of having a whole range of factors for achieving the much-needed encouraging entrepreneurial environment. Especially now when the Covid-19 pandemic has hit developing economies hard, segments like entrepreneurial education and women entrepreneurship would benefit from a systematic approach of policymakers. This could be a beacon of hope for these societies in order to adapt, recover, and also use this crisis to build a sustainable development on the basis of newly formed entrepreneurial activity.

Regional Romanian research pointed out the importance of understanding the factors that contribute to the development of entrepreneurial activity that bring sustainable economic growth [12]. In addition, they confirm that achievement of effective entrepreneurship educative programs requires implementation of communication skills as well as empathy-building and assertiveness trainings for potential entrepreneurs. These programs could also help potential female entrepreneurs develop much needed confidence to start their own entrepreneurial ventures. 
Authors Metcalfe and Rees [17] support the thesis that women entrepreneurship is not being utilized in the best possible way in developing countries due to a very specific political and cultural context. Authors Syed and Metcalfe [18] in their research paper cite Luke and Munshi [19] who also agree that women's contribution is crucial for a developing society. Research of Bastian and Metcalfe [20] also confirms the importance of gender equality for the development of entrepreneurship as a key factor in building sustainable economic growth. They state in their paper that: The United Nations Development Program (UNDP) (2015) identified gender inequality as a key contributor to the loss of human development and declared "gender equality" as a sustainable development goal (SDG) in the UN 2030 agenda (p. 1) [21]. Gender equality is in the focus of the World Bank as the key to sustainable development [22]. All this clearly points to the fact that women entrepreneurship and education programs that foster entrepreneurial activity are crucial factors to be especially supported in developing countries like Serbia, Bosnia, and Herzegovina.

\section{Theoretical Framework}

In this research, we focus on the KAI model and its three dimensions and their relation to entrepreneurial potential of students. The Kirton Adaptation-Innovation model (KAI) developed by Michael Kirton has proven to be a very adaptable theory framework for the examining of problem-solving styles [23]. The main aim of this model is to explain individuals' cognitive propensity and creativity style of problem solving [24-26].

Different people have different ways of analyzing and solving problems. Cognitive researchers observe these differences in order to find entrepreneurs [27]. Menold et al. [28] consider in their research that students must develop necessary skills in order to be successful in solving problems in a fast and changing modern economy that asks for creative and innovative approaches. The Kirton Adaptation Innovation theory states that individuals have different problem solving styles and that their position on this continuum can be determined from adaptive behavior to innovative behavior on three cognitive styles: originality, efficiency, and rule governance [24].

Originality shows individuals' creativity; efficiency is linked to a person's precision, reliability, and discipline; and rule conformity relates to a person's respect for rules and authority [29]. The efficiency (E) is a subfactor that shows to which extent people pay attention to detail in solving various problems. Within this dimension, the adapter tends to slowly advance towards its goal, while the inventor does not pay much attention to detail and is much more expeditious. This is, however, the best way to create a change and something "new", which is the innovator's goal.

The second dimension constitutes acceptance of the Group Policy (RC); this dimension of KAI model describes the relationship of the structure within which occurs problem solving. Adaptors are concerned about the acceptability of their actions by the environment and respect the rules and the existing structure, also considering that the existing rules can contribute more effectively to solving existing problems, and innovators do not pay much attention to the rules or reaction that their actions could produce in society, and consider that the rules only limit the number of solutions for efficient solvation of the problem.

The third dimension of originality characterizes types of relationships that different people have towards ideas. Adaptors offer a small number of ideas and find a few standard already established ways of solving the problem, while innovators offer many new ideas and untried solutions that are quite unique, risky, and if received, could influence in change of the existing structure [30,31].

According to Gerry et al. [32] who in their research focused on the factors of students propensity in order to define entrepreneurial potential used [33] and view of an entrepreneur, an entrepreneur is "an individual (student) who (accepts the possibility that he or she might) establish and manage a business for the principal purposes of profit and growth". In this paper, we will research the relations of the KAI model's three cognitive styles of originality, efficiency, and rule conformity; and the entrepreneurial potential 
dimensions of the model of Entrepreneurial Traits (QET) and the model of entrepreneurial potential (SEP). Dimensions of the QET model consist of six dimensions: unconventionality and creativity; focus on achievement and acceptance of challenges entrepreneurial self-efficacy, assertiveness and communication, positive attitudes toward entrepreneurship, interest in entrepreneurship, and knowledge. The SEP model of entrepreneurial potential focuses on dimensions of intellectual abilities, self-confidence, motivation, social relations, constitutions, emotionality, extroversion, and organizational skills.

Doyle et al. [34] in their research found a connection between the will to become an entrepreneur and cognitive styles. Cognitive style shows how different individuals process information from their surroundings and how they act on the basis of that information [27]. Isaksen and Puccio [35] found that creative style originality is significantly linked to communication skills. Individuals that are very creative are not usually very extroverted persons, but they possess a high level of confidence, assertiveness, and independence [36]. Cromie [37] concluded that self-confidence might actually be a result of entrepreneurship rather than the predictor.

Jaskyte and Kisieliene [38] found researching relations of creativity to three KAI model dimensions of originality, efficiency, and conformity a very strong relation between originality and creativity. Challenge and intrinsic motivation subscales were as well positively related to creativity, while conformism and rule conformity are not related to creativity [39]. Conformity holds on to customs and traditions, while creativity is always related to new perspectives [40]. Creativity precedes innovation [7]. Miron-Spektor et al. [41] concludes that originality is significantly related to creating ideas whereas group conformity and efficiency are responsible for the execution process of those ideas and that teams with no conformists have a lower confidence in the process of implementation of their ideas. Engl et al. [11] in their study used the KAI model in order to try and recognize entrepreneurs among other employees in a corporation; their results showed obvious differences between entrepreneurs and other employees in research concerning their KAI conformity dimension, which led them to a conclusion that entrepreneurs have lack of consideration for authority and rules opposite to employees. Conformist individuals give stability to a team by respecting the rules and provide a framework that positively influences innovation, which leads to entrepreneurship [42].

Helson and Pals [43] concluded that individuals with creative potential are related to openness, complexity, unconventionality, and intellectuality. Hutchinson and Skinner [44] in their concluding remarks advise students and educators that conscientiousness, emotional stability, and openness are as well significantly related to entrepreneurial potential and should be put in focus if their aim is fostering entrepreneurship. Research results from Gurel et al. [45] and Gurol and Atsan [46] show that student populations with higher risk-taking propensity and higher innovativeness possess more entrepreneurial potential. Zani et al. [47] also concluded in their study on personal characteristics and their relation towards entrepreneurial potential that creativity and risk taking are significantly related to entrepreneurial potential. Entrepreneurial initiative is seen as pro-active and a problemsolving attitude [48]. Zhao et al. [49] and Wilson et al. [50] pointed out in their studies that entrepreneurship is in correlation with entrepreneurial-self efficacy. As creativity is positively correlated to fun and challenge intrinsic motivation dimensions are important for individuals to be in a creative stage, out of box acting and initiatives are needed so they could feed their need for curiosity, which is strongly related to intrinsic motivation [38].

Based on the literature review, the main research question of this study is the examination of relations of Kirton's model [24-26] with the dimensions of student's entrepreneurial potential, with the ultimate aim of clarifying the complexity of the relation between individual characteristics and factors that contribute and represent one of the most important preconditions for youth entrepreneurship. Therefore, the main research question in this paper can be formulated as follows: what are the relations between the basic dimensions of Kirton's model [24-26], on the one hand, and the dimension of development of entrepreneurial potential of the student population, on the other? This research will examine 
if these dimensions are correlated and what types of relations characterize them among students in more developed countries, and students in countries that are in the process of social transition. The contribution of this research would be reflected in elucidating the complex relationship of internal individual characteristics and factors that predispose young people to engage in entrepreneurship in developed countries, but also in those that are in the process of intensive development and socio-economic transformation.

Previous studies have dealt with the relationship of these factors primarily by testing certain conceptual models and the relationships of theoretical constructs $[10,11]$. However, the value and contribution of this research is reflected in the fact that examining the relationship between key dimensions of the KAI model and of the characteristics of entrepreneurial potential of the student population, in a specific, current context of social changes is characteristic for developing countries and the education of young generations in these countries. Different types of research studies have focused on defining entreprenurial potental providing their view of this phenomenon [33,51]. Their research results varied as this phenomenon is influenced by a number of factors that were also in the focus of recent research efforts. Authors defined entreprenurial potential as a combination of social and behavioral characteristics and investigated its influence on economic development. Factors such as education, gender, and family influence were also examined [32,52,53]. Our current research differs from the above-mentioned ones because it focuses specifically on the dimensions of the KAI model, evaluating relations between the originality, efficiency, conformism, and entrepreneurial potential of students in the fast changing business environment.

\section{Research Methodology}

The aim of this study is the evaluation of the significance of all three KAI model dimensions and their relation to the entrepreneurial potential of the student population and the recognition of guidelines to the development of entrepreneurship potential in young adults. This paper researches the relations of the KAI model's three cognitive styles of originality, efficiency, and rule conformity and entrepreneurial potential dimensions of the Questionnaire on Entrepreneurial Traits (QET) and the Scale of Entrepreneurial Potential (SEP).

\subsection{Data Collection and Descriptive Statistics}

The sample consisted of students from three different countries, two candidate EU countries Serbia and Bosnia, and one EU member country Belgium. The student sample was gathered from three universities and eleven faculties. The sample consisted of 1008 students of which 589 were male and 419 were female students. The research was conducted during the school year 2016/2017 and complied with ethical standards regarding obtaining the consent of the institutions where the research was conducted, students filled out questionnaires during classes, respecting the anonymity of respondents, and using data exclusively for research purposes. We can conclude that the participants understood the instructions well and no difficulties were recorded in the process of collecting data.

\subsection{Instruments}

The Adaption-Innovation theory developed by Michael Kirton [24-26] explains the cognitive propensity and creativity style of problem solving. Michael Kirton developed a scale to measure different cognitive styles. The KAI inventory consists of 32 items constructed to manifest different cognitive styles of creativity, problem-solving, and decisionmaking. Every item scores on a scale from 1 to 5, creating a continuum of total scores extending from 32 to 160, with a theoretical mean of 96. Kirton [24] stated, "The contention ... is that everyone can be located on a continuum ranging from an ability to "do things better" to an ability to "do things differently", and the ends of this continuum are labeled adaptive and innovative, respectively" (p. 622). The higher the score, the more innovative is the individual's decision-making and problem-solving style. Individuals that have an adaptive style will score from 60-90 on the KAI scale. Individuals with innovative style 
will score from 110-140. Later on, the inventory was categorized into three subscale factors: efficiency $(E)$, rule/group conformity $(R / C)$, and originality $(O)[24,26]$. Each of these three factors corresponds to different sections of the inventory with the goal to gain more exact results. All responses were obtained on a 5-point Likert's type scale-from strongly agree to strongly disagree. Confirmatory factor analysis confirmed the factor structure of the questionnaire. In this study, the instrument showed an adequate metric characteristic of reliability (Chronbach's $\alpha=0.742-0.767$ per subscale).

In addition to Adaption-Innovation, the other two instruments were SEP scale of entrepreneurial potential and Questionnaire of Entrepreneurial Traits (QET). SEP scale of entrepreneurial potential focuses on eight different subscales: intellectual abilities, selfconfidence, motivation, social relations, constitutions, emotionality, extroversion, and organizational skills. The subscale of intellectual abilities includes resourcefulness in different situations, ability to independently solve problems, ability to independently make important decisions, and willingness to learn and improve. The self-confidence subscale includes boldness in expressing our own views, while the subscale of constitution relates to physical fitness energy level and endurance. The subscale of organizational skills includes preference towards management and high organizing skills. The openness subscale incorporates risk taking propensity, openness to everything that is new and creativity. Competitive spirit and grit tendency, taking the initiative, success in achieving the objectives, ambitiousness, perseverance, work dedication, persistence and diligence all belong to the subscale of motivation. The subscale of emotionality includes the ability of self-control, stress resistance, emotional stability, and optimism. The subscale of social relations includes striving for leadership in the group, communicativeness, dominance in social relationships, teamwork preference, flexibility and adaptability, ability to solve conflicts, ability to make an impression on the social surroundings. The SEP inventory consists of 34 items constructed to measure the score of respondents on the dimensions of expression of entrepreneurial potential. Total score is calculated as the sum of scores on all subscales; a higher score on the scale indicates a stronger entrepreneurial potential. This inventory was created for the needs of this research on the bases of theoretical assumptions and previous research in the field of entrepreneurial characteristics. All responses were obtained on a 5-point Likert's type scale from strongly agree to strongly disagree. Confirmatory factor analysis confirmed the factor structure of the questionnaire. In this study the instrument showed adequate metric characteristic of reliability (Chronbach's $\alpha=$ 0.751-0.756 per subscale).

The Questionnaire on Entrepreneurial Traits (QET), entrepreneurial self-efficacy and attitudes towards entrepreneurship was constructed by Gracanin and Coso [54]. The QET inventory consists of 58 items. This inventory measures on six subscales: entrepreneurial unconventionality and creativity; focus on achievement and acceptance of challenges, entrepreneurial self-efficacy, assertiveness and communication, positive attitudes toward entrepreneurship, interest in entrepreneurship and knowledge. Total score is calculated as the sum of scores on all subscales; a higher score on the scale indicates a stronger entrepreneurial potential. The subscale of unconventionality and creativity refer to the tendency of uncommon and new ways of solving problems that involve risk taking, and the perception of one's own creativity, and confidence in you regardless of these characteristics. The subscale of focus on achievement and acceptance of challenges relates to the individual's desire to try new ways of solving difficult tasks i.e., to accept challenges and activities that may or may not have led to success. The subscale of entrepreneurial self-efficacy is the largest and most important scale in the questionnaire, and refers to the confidence in one's entrepreneurial characteristics, the persistence of the individual in general, the entrepreneurial propensity and the leader characteristics. The subscale of assertiveness and communication refers to two features that can be very useful in entrepreneurial activities. The subscale of positive attitudes toward entrepreneurs and interest in entrepreneurship refer to a positive attitude towards entrepreneurs and entrepreneurship, and one's own willingness to become an entrepreneur. The subscale of self-perceived knowledge about 
entrepreneurship refers to the individual's own views on how much they know and how much they recently learned about entrepreneurship. All responses were obtained on a 5 -point Likert-type scale from strongly agrees to strongly disagree. Confirmatory factor analysis confirmed the factor structure of the questionnaire. In this study the instrument showed adequate metric characteristic of reliability (Chronbach's $\alpha=0.732-0.805$ per subscale).

\subsection{Data Analysis}

In this study we used Statistica and SPSS program packages for the data processing. The processing methods applied for examining the existence and intensity of relationships between variables were measures of descriptive statistics and canonical correlation analysis.

\subsection{Results}

Canonical correlation analysis revealed a significant relationship between the dimensions of the KAI model and subscales of the QET model $\left(\mathrm{Rc}=0.565, \chi^{2}(\mathrm{df}=18)=595,074\right.$, $p<0.01)$.

Results for the first pair in Table 1. showed that individuals who had a higher score on originality and efficiency have a higher score on all sub-scales of the QET model, particularly on the focus on achievement and meeting the challenges, unconventionality, creativity, and entrepreneurial self-efficacy. For the second pair $\left(\mathrm{Rc}=0.421, \chi^{2}(\mathrm{df}=10)\right.$ $=210.219, p<0.01$ ), the results showed that individuals who had higher scores on all dimensions of the KAI model, in particular on the efficiency and conformity, have a higher score on the entrepreneurial self-efficacy, assertiveness, and communication, and the lower score on the unconventionality and creativity subscales. For the third pair $(\mathrm{Rc}=0.121$, $\left.\chi^{2}(\mathrm{df}=4)=14.676, p<0.01\right)$, the results showed that people who have a higher score on the conformity and lower on the efficiency sub-scale have higher scores on knowledge and less positive attitudes towards entrepreneurs and interest in entrepreneurship, and lower focus on achievement and meeting the challenges. Height includes variance and redundancy by canonical factors and confirms the relevance of the canonical correlation coefficients. Canonical loadings are shown in Table 2.

Table 1. Strength and significance of the relationship between factors of the three canonical pairs.

\begin{tabular}{|c|c|c|c|c|c|c|c|c|c|}
\hline \multirow{2}{*}{$\begin{array}{c}\text { Ordinal Number } \\
\text { of the Pair }\end{array}$} & \multirow[b]{2}{*}{$\mathbf{R}_{\mathrm{c}}$} & \multirow[b]{2}{*}{$\Lambda_{W}$} & \multirow[b]{2}{*}{$x^{2}$} & \multirow[b]{2}{*}{ df } & \multirow[b]{2}{*}{$p$} & \multicolumn{2}{|c|}{ Left Set } & \multicolumn{2}{|c|}{ Right Set } \\
\hline & & & & & & Range & Redundancy & Range & Redundancy \\
\hline 1. & 0.565 & 0.552 & 595.074 & 18 & 0.000 & 0.332 & 0.106 & 0.401 & 0.128 \\
\hline 2. & 0.421 & 0.811 & 210.219 & 10 & 0.000 & 0.509 & 0.090 & 0.151 & 0.027 \\
\hline 3. & 0.121 & 0.985 & 14.676 & 4 & 0.005 & 0.159 & 0.002 & 0.119 & 0.002 \\
\hline
\end{tabular}

Canonical correlation analysis revealed a significant relationship between the dimensions of the KAI models and sub-scales of the SEP model $\left(\mathrm{Rc}=0.655, \chi^{2}(\mathrm{df}=24)=824.515\right.$, $p<0.01$ ).

The results of the first pair in Table 3. showed that individuals who had a higher score on originality and efficiency subscales, have a higher score on all dimensions of SEP models, especially on the motivation, intellectual capacity, and social relations subscales. For the second pair $\left(\mathrm{Rc}_{\mathrm{c}}=0.438, \chi^{2}(\mathrm{df}=14)=262.997, p<0.01\right)$, the results showed that individuals who had higher scores on efficiency and conformity have a higher score on motivation and lower score on openness. For the third pair $\left(\operatorname{Rc}=0.220, \chi^{2}(\mathrm{df}=6)=49.887\right.$, $p<0.01$ ), the results showed that individuals with a higher score on conformity have higher scores on emotionality, social relations, and the constitutions. Height includes variance and redundancy by canonical factors and confirms the relevance of the canonical correlation coefficients. Canonical loadings are shown in Table 4. 
Table 2. Canonical loadings.

\begin{tabular}{lccc}
\hline \multicolumn{1}{c}{ Left Set } & 1. Pair & 2. Pair & 3. Pair \\
\hline Originality & $-0.924^{*}$ & $-0.309^{*}$ & 0.225 \\
Efficiency & $-0.343^{*}$ & $-0.819^{*}$ & $-0.460^{*}$ \\
Conformisam & 0.154 & $-0.872^{*}$ & $0.464^{*}$ \\
\hline \multicolumn{1}{c}{ Right Set } & 1. Pair & 2. Pair & 3. Pair \\
\hline Unconventionality and creativity & $-0.753^{*}$ & $0.582^{*}$ & -0.083 \\
Focus on achievement and meeting the & $-0.851^{*}$ & -0.231 & $-0.350^{*}$ \\
challenges & $-0.721^{*}$ & $-0.595 *$ & -0.092 \\
$\begin{array}{l}\text { Entrepreneurial self-efficacy } \\
\text { Assertivness and communication skills }\end{array}$ & $-0.576^{*}$ & $-0.372 *$ & 0.173 \\
$\begin{array}{l}\text { Positive attitudes of entrepreneurs and interest } \\
\text { in entrepreneurship }\end{array}$ & $-0.375^{*}$ & 0.110 & $-0.494 *$ \\
Knowledge & $-0.355^{*}$ & -0.104 & $0.547 *$ \\
\hline
\end{tabular}

*Statistically significant structural coefficient.

Table 3. Strength and significance of the relationship between factors of the three canonical pairs.

\begin{tabular}{|c|c|c|c|c|c|c|c|c|c|}
\hline \multirow{2}{*}{$\begin{array}{c}\text { Ordinal Number } \\
\text { of the Pair }\end{array}$} & \multirow[b]{2}{*}{ Rc } & \multirow[b]{2}{*}{$\Lambda_{W}$} & \multirow[b]{2}{*}{$x^{2}$} & \multirow[b]{2}{*}{ df } & \multirow[b]{2}{*}{$p$} & \multicolumn{2}{|c|}{ Left Set } & \multicolumn{2}{|c|}{ Right Set } \\
\hline & & & & & & Range & Redundancy & Range & Redundancy \\
\hline 1. & 0.655 & 0.439 & 824.515 & 24 & 0.000 & 0.483 & 0.207 & 0.533 & 0.229 \\
\hline 2. & 0.438 & 0.769 & 262.997 & 14 & 0.000 & 0.264 & 0.051 & 0.065 & 0.012 \\
\hline 3. & 0.220 & 0.951 & 49.887 & 6 & 0.000 & 0.253 & 0.012 & 0.070 & 0.003 \\
\hline
\end{tabular}

Table 4. Canonical loadings.

\begin{tabular}{lccc}
\hline \multicolumn{1}{c}{ Left Set } & 1. Pair & 2. Pair & 3. Pair \\
\hline Originality & $-0.932^{*}$ & -0.298 & -0.206 \\
Efficiency & $-0.730^{*}$ & $0.682^{*}$ & 0.052 \\
Conformisam & -0.218 & $0.489^{*}$ & $-0.845^{*}$ \\
\hline \multicolumn{1}{c}{ Right Set } & $\mathbf{1 . ~ P a i r}$ & 2. Pair & 3. Pair \\
\hline Intellectual abilities & $-0.841^{*}$ & 0.016 & 0.026 \\
Self confidance & $-0.684^{*}$ & $-0.322^{*}$ & 0.103 \\
Motivation & $-0.915^{*}$ & $0.372^{*}$ & -0.031 \\
Social relations & $-0.786^{*}$ & -0.131 & $-0.381^{*}$ \\
Constitutions & $-0.617^{*}$ & 0.111 & $-0.310^{*}$ \\
Emotionality & $-0.462^{*}$ & 0.054 & $-0.514^{*}$ \\
Opennes & $-0.768^{*}$ & $-0.485 *$ & -0.110 \\
Organization skills & $-0.669^{*}$ & 0.106 & 0.182 \\
\hline
\end{tabular}

* Statistically significant structural coefficient.

\section{Discussion}

The main objective of this research paper was the examination of the relations between the basic dimensions of the Kirton's model [24-26], with dimensions of development of entrepreneurial potential of students' population, with the ultimate aim of clarifying the complexity of the relation between individual characteristics and factors which contribute, and constitute one of the most important preconditions for the development of youth entrepreneurship. In accordance with Kirton's theoretical model [24], the conceptual assumptions that determines a set of individual characteristics that essentially constitute entrepreneurial potential $[13,35,45,46]$ as well as with the findings of previous studies that dealt with individual characteristics which predispose young people for entrepreneurial occupations $[1,3,4]$, the basic premise was that the three basic dimensions of the KAI model-originality, conformity, and efficiency-are significantly associated with the dimensions of development of students entrepreneurial potential. The study confirmed the 
hypothesis of the research, showing that there are different patterns of relation between Kirton's dimension of originality, conformity, and efficiency and examined dimensions of entrepreneurial potential, within the QET and SEP models of entrepreneurial dimensions. It can help to foster weak entrepreneurial skills and potentials of youth population in developing countries.

\subsection{Relations between Dimensions of the KAI Model and Dimensions of the QET Model}

The results of the canonical correlation analysis indicate the existence of three significant correlation patterns between the investigated dimensions of the KAI model and dimensions of the QET models; statistics showed that people who had a higher score on originality and efficiency subscales had higher scores on all dimensions of the QET model, especially on the subscales of focus on achievement and meeting the challenges, unconventional creativity and entrepreneurial self-efficacy. Taking into account the characteristics of people who achieve high scores on the KAI model dimensions of originality and efficiency, this result was expected. This model explains that individuals who tend to create proliferation of new ideas and non-standard solutions, which often carry a certain amount of risk, are also predisposed to rapid progress toward the solution of the problem, without paying excessive attention to the small details; instead, they strive with big steps toward their ultimate goal, at the same time they possess to a large degree individual characteristics that form the basis of entrepreneurial potential. These individuals are especially driven towards the achievement and welcome challenges of various kinds; they are not prone to the established routine. They are unconventional and creative in their approach to different life situations and have a developed sense of entrepreneurship self-efficacy, which is in line with their entrepreneurial nature and with the overall focus of achieving their goals. This kind of direct and proactive effort, inclination towards fast solutions, deviation from the existing schemes, and established rules leads to a sense that they independently control the situation, and their feeling of success further reinforces the original efforts and proactive approach — these are all characteristics essential for entrepreneurship $[4,11,38,49,50]$.

Another pattern of relation suggests that young people who have developed all the characteristics of the KAI model, especially efficiency and conformity, achieve higher scores on the dimensions of the entrepreneurial potential-entrepreneurial self-efficacy, assertiveness, and communication, and less on unconventionality and creativity. This pattern of correlation indicates that high experience of entrepreneurial self-efficacy, also propensity to express their opinion in an appropriate way and represent their own personal needs and attitudes in communication with the surroundings, have young people who are inclined to efficiently access their duties and set objectives, without paying greater attention to the details, but more within the limits set by generally accepted norms and rules, and less deviating from accepted norms and expectations of the surroundings. For entrepreneurship, in addition to originality and preference for creative solutions, it is extremely important to have a certain amount of sensitivity for the social environment itself, to understand the expectations and requirements of the social environment, be inclined to align one's messages with the expectations of the environment, as well as express and implement one's own efforts in a socially acceptable way, which the following studies research [13,38,40-42]. Every kind of competitiveness requires a certain amount of caution and the compliance of its own efforts with the existing framework, habitual patterns of the profession, ethical and legal frameworks, etc. Therefore, this set of individual characteristics is also very important for entrepreneurship [40-42]. The third pattern of individual characteristics shows that students who achieve higher scores on conformity and less on efficiency have higher scores on the knowledge and less positive attitudes towards entrepreneurs and interest in entrepreneurship as well as a smaller focus on the achievement and acceptance of challenges. This pattern really displays characteristics that distinguish young people, who have not developed the entrepreneurial potential, i.e., they are not inclined to dealing with entrepreneurship. Such individuals are prone to acceptance of the general group rules, established patterns of behavior, and expected norms of social environment. Concerning 
task accession, they are systematic, detailed, and consistent. They take care of every little detail and these individuals are analytical in the process of solving problems, for which they are ready to invest large efforts, representing a long-term process, while at the same time, they are far less focused on rapid implementation of the objectives and hasty actions, without detailed consideration. These people are well informed about different things, have a broad theoretical knowledge, but they are not aimed directly at the rapid achievement and acceptance of different challenges. They prefer to work within the familiar framework and established rules; their natures are conservative and are not prone to taking any risks. As this study has shown, in accordance with their general nature, they are not interested in entrepreneurship, nor do they have a positive opinion about entrepreneurs, although they have some knowledge about it, other research results offer evidence of this as well $[11,39,40]$. Individuals like these represent the potential of the society, which needs extra work in order to encourage their entrepreneurial potential. It is important that their broad knowledge, skills, systematic nature, and tendency towards planning, which are also important characteristics for entrepreneurship, are directed towards encouraging the development and subsequent realization of entrepreneurial capacity $[11,39,40]$.

\subsection{Relations between Dimensions of the KAI Model and Dimensions of the SEP Model}

Canonical correlation analysis revealed a significant association between dimensions of the KAI model and subscales of the SEP model. The first pattern showed that people who had higher scores on originality and efficiency have higher scores on all dimensions of the SEP models, especially on the subscales of motivation, intellectual capacity and social relations. This pattern suggests that creative people tend to take risks and search for new solutions and rapid progress towards the goals, with a proactive approach. At the same time, they possess a set of desirable entrepreneurial characteristics-developed motivation and the tendency to take the initiative, focus on tasks and ambitiousness, diligence, perseverance and persistence in achieving their goals. In addition, proper intellectual capacity, such as resourcefulness in different situations, the ability to solve problems independently and capability to make important decisions, as well as the ability to establish appropriate social relationships, in which they can behave as leaders, with confidence in their approach, but at the same time know how to express their own needs in an appropriate manner and in the social environment actively advocate for their ideas and goals, but with a dose of adaptability and flexibility, respecting the rules of teamwork, which is confirmed in other studies that have investigated the relationship of entrepreneurial dimension $[36-38,43,48]$. It is a set of these entrepreneurial characteristics that represent an ideal that we should strive for as much as possible, and aspire to encourage and develop in young people who do not possess enough of such characteristics [44]. The second pattern shows that young people who achieve better results in efficiency and conformism have a higher score on motivation and lesser score on openness. This finding suggests that young people are prone to rapid progress and effective implementation of the objectives, but within the existing and long-established patterns and rules they actually are very motivated, persistent, and dedicated to the realization of the goals; at the same time, they lack a certain level of propensity to take risks and step out of existing borders and frames. When it comes to the context of entrepreneurial potential and propensity to deal with entrepreneurship, this arrangement is beneficial and significantly represents equilibrium and certain stability in the processes. It is desirable in situations that are inherently predictable, and do not represent a challenge and a request for adaptation to new circumstances [41,42]. However, the practice of entrepreneurship is often a very challenging process; just including the decision to address it implies a certain amount of risk-taking, and for this category of young people it is necessary to develop openness to new situations, and courage to rise from the existing framework, in order to improve their own potential, but also the social environment in which they live [45-47].

The third pattern of relation suggests that young individuals who are more predisposed to conformism are at the same time achieving higher scores on the dimensions of 
emotionality, social relations, and constitution. Thus, individuals who accept the rules of the environment and are trying to fit into existing social patterns and generally accepted principles will better develop certain characteristics that are part of the entrepreneurial potential, and these characteristics refer to the developed emotional stability, self-control skills, and good control of affects. These individuals will be more resistant to stressful experiences and optimistic about the realization of their goals and future expectations. Their stable nature leans towards the known and expected, and respects the valid and accepted principles and rules, contributes in making them feel more secure, helps them to tolerate stressful experience in an easier manner, and to absorb an optimistic view of the events [44]. These people are safer in their social relations as well, they are able to take the lead when necessary, but at the same time represent their goals in a socially acceptable and appropriate manner, taking into account the needs and expectations of others. When it comes to the constitution characteristic, these are powerful, energetic individuals, in good physical shape, and durable - these are all predictors of entrepreneurial potential [33].

Accordingly, it can be concluded that in addition to openness and risk propensity, which are traditionally associated with desirable traits of entrepreneurial potential [45,46], general harmony of individual capacity is very important for entrepreneurship, which indicates a strong tendency to respect environmental standards and respect for social environment rules, and performs within the framework of these generally accepted norms and values; other research works conclude the same [41,42].

\section{Conclusions}

The results provide new insights into how the KAI model can be designed to reflect the post socialist entrepreneurship education context. Our study extends knowledge in the field of entrepreneurship education, and contributes to emerging debates in the political economy of entrepreneurship development. These findings are positioned within contemporary debates about the role of entrepreneurship education in sustainable development, and in SDG attainment in post socialist states.

This he research confirmed the existence of relations and revealed the complex relationship between the dimensions of the KAI model and characteristics of entrepreneurial potential. It also showed that there are different patterns of association between Kirton's dimensions of originality, conformity, and efficiency and tested dimensions of entrepreneurial potential in the student population. The established patterns of relations discuss a set of individual characteristics that students tend to possess, and are important for entrepreneurship. They also point to the potential of the various modes and programs that should be developed in young people, in order to encourage and enable them to engage in entrepreneurship, which is of particular importance for countries outside the EU, who are in stages of social transition and intensive development. The academic community in Serbia and Bosnia should foster the entrepreneurship potential of students by creating an environment that will support and give clear guidelines in order to enable students to develop characteristics that enhance entrepreneurial potential. According to the results of this research, these characteristics focus on achievement, meeting challenges, unconventional creativity, entrepreneurial self-efficacy, tendency to take initiatives, focus on tasks, ambitiousness, diligence, perseverance, persistence, ability to solve problems independently and capability of making important decisions, as well as the ability to establish appropriate social relationships, in which students would behave as leaders, with confidence in their approach. The student population represents the country's most valuable resource and its base of intellectual capital and the right approach of the academic community and help of state institutions can provide the required environment that will develop entrepreneurship, and help develop the economic situation in the region.

The potential limitations of this study are reflected in the limited selection of countries from which the study participants come from. Thus, in future research, it would be particularly useful to expand the sample of covered countries, i.e., to examine the relationships between appropriate individual characteristics and predispositions for entrepreneurship in 
a larger number of countries. It would be interesting to compare students from older EU member countries that have been part of the EU since it was formed, as well as younger member countries, mostly from the Eastern European bloc and other countries that are currently in the process of joining the EU. In addition, it would be desirable to include younger generations, such as primary and especially secondary school students, as entrepreneurial potential needs to be monitored, developed, and encouraged during the earlier stages of education. It would definitely be extremely important to link and develop these traits with different factors of the micro and macro-social environment, in different age generations.

The practical implications for participants in the educational process and for policymakers are reflected in the possibilities of creating new study programs in undergraduate and postgraduate studies. The aim of this would be to encourage and develop those characteristics that this research proved to be key predispositions for entrepreneurship in younger generations in developed as well as developing countries. In addition, the existing study programs need to be revised and the possibility of introducing new obligatory or elective courses and modules, which would be aimed at encouraging entrepreneurial potential among students, should be considered. This is not only meant for programs that are traditionally economically and market-oriented, but also other profiles that need to be further trained to encourage entrepreneurial capacity and develop features that are part of this potential important for the sustainability of modern society as a whole. In this sense, government professional bodies have a great importance and responsibility, which is reflected through plans and active support that encourage and guide this process of improving formal education at various levels of education. Great importance belongs to non-governmental organizations and the network of international organizations that deal in various ways with young people, their education, and the development of the potential of young generations for active participation in a modern society of intensive change. These organizations can, through various projects in the local community and by connecting and networking at the international level, actively contribute to the development of entrepreneurial characteristics of young people, both locally and by connecting young members of different communities and cultures. Given that entrepreneurship has a significant cultural aspect as well, through a carefully planned exchange of ideas and experiences in different cultural contexts, it could be raised to an even higher level. Encouraging entrepreneurial potential among young people, through networking in local communities and cultural exchange between countries of different levels of development, contributes to the progress and sustainability of the societies as a whole, regardless of the stage of socio-economic development they are currently at.

Author Contributions: Conceptualization, M.M., M.S. and B.D.; methodology, M.M., M.S., B.D., B.M., N.B. and S.M.; software, S.M. and B.D.; validation, M.M., B.D. and S.M.; formal analysis, M.S., B.D., N.B. and S.M.; investigation, M.M., M.S. and B.M.; resources, M.S., B.M.; data curation, M.M., M.S., B.D., B.M., N.B. and S.M.; writing—original draft preparation, M.M., M.S. and B.M.; writingreview and editing, M.M., and M.S.; visualization, B.D. and S.M.; supervision, M.M., M.S., B.D., B.M., N.B. and S.M. All authors have read and agreed to the published version of the manuscript.

Funding: This research received no external funding.

Institutional Review Board Statement: The study was conducted according to the guidelines of the Declaration of Helsinki, and approved by the institutional review board of University of Novi Sad, Serbia (protocol code number 012-199/28-2016 and the date of approval is 22nd of September 2016).

Informed Consent Statement: Informed consent was obtained from all subjects involved in the study.

Data Availability Statement: Data is not publicly available, though the data may be made available on request-from the corresponding author.

Conflicts of Interest: The authors declare no conflict of interest. 


\section{References}

1. Ang, S.H.; Hong, D.G.P. Entrepreneurial spirit among East Asian Chinese. Thunderbird Int. Bus. Rev. 2000, 42, 285-309. [CrossRef]

2. Mitrovic, S.; Borocki, J.; Sokolovski, V.; Nesic, A.; Melovic, B. Potential of young entrepreneurs: Is there any possibility of their development through education? New Educ. Rev. 2013, 32, 288-298.

3. Rauch, A.; Frese, M. Psychological approaches to entrepreneurial success. A general model and an overview of findings. In: Cooper, C.L., Robertson, I.T. (Eds.) International review of industrial and organizational. Int. Rev. Ind. Organ. Psychol. 2000, 15, 101-142.

4. Yan, J. The Impact of Entrepreneurial Personality Traits on Perception of New Venture Opportunity. N. Engl. J. Entrep. 2010, 13, 4. Available online: http:/ / digitalcommons.sacredheart.edu/neje/vol13/iss2/4 (accessed on 2 February 2021). [CrossRef]

5. Brockhaus, R.H. Risk Taking Propensity of Entrepreneurs. Acad. Manag. Proc. 1976, 1976, 457-460. [CrossRef]

6. Reynolds, P.D. New firms: Societal contribution versus survival potential. J. Bus. Ventur. 1987, 2, 231-246. [CrossRef]

7. Amabile, T.M. Stimulate Creativity by Fueling Passion. Blackwell Handb. Princ. Organ. Behav. 2017, 331, 345-356. [CrossRef]

8. Malecki, E.J.; Spigel, B. Innovation and Entrepreneurship; Routledge: Abingdon, UK, 2017; ISBN 9781782548522.

9. Hult, G.T.M.; Hurley, R.F.; Knight, G.A. Innovativeness: Its antecedents and impact on business performance. Ind. Mark. Manag. 2004, 33, 429-438. [CrossRef]

10. Goldsmith, R.E.; Kerr, J.R. Entrepreneurship and adaption-innovation theory. Technovation 1991, 11, 373-382. [CrossRef]

11. Engle, D.E.; Mah, J.J.; Sadri, G. An empirical comparison of entrepreneurs and employees: Implications for innovation. Creat. Res. J. 1997, 10, 45-49. [CrossRef]

12. Bosma, N.; Hill, S.; Ionescu-Somers, A.; Kelley, D.; Levie, J.; Tarnawa, A. GEM Global Report 2019/2020; Global Entrepreneurship Research Association: London, UK, 2020; ISBN 978-1-9160178-3-2.

13. Ateljevic, J.; O'Rourke, T.; Todorovic, Z. Entrepreneurship and SMEs in Bosnia and Herzegovina. Int. J. Entrep. Innov. 2004, 5, 241-253. [CrossRef]

14. Herrington, M.; Kew, J.; Kew, P. Tracking Entrepreneurship in South Africa: A Gem Perspective; Graduate School of Business, University of Cape Town: Cape Town, South Africa, 2017; ISBN 0799223603.

15. Ruda, W.; Martin, T.A.; Danko, B. Target group-specific design of student entrepreneurship support-A German example focusing on start-up motives and barriers. Acta Polytech. Hung. 2009, 6, 5-22.

16. Lingelbach, D.C.; De La Vina, L.; Asel, P. What's Distinctive about Growth-Oriented Entrepreneurship in Developing Countries? SSRN Electron. J. 2005. [CrossRef]

17. Dawn Metcalfe, B.; Rees, C.J. Gender, globalization and organization: Exploring power, relations and intersections: GUEST EDITORIAL. Equal. Divers. Incl. 2010, 29, 5-22. [CrossRef]

18. Syed, J.; Metcalfe, B.D. Under western eyes: A transnational and postcolonial perspective of gender and HRD. Hum. Resour. Dev. Int. 2017, 20, 403-414. [CrossRef]

19. Luke, N.; Munshi, K. Women as agents of change: Female income and mobility in India. J. Dev. Econ. 2011, 94, 1-17. [CrossRef]

20. Bastian, B.L.; Metcalfe, B.D.; Zali, M.R. Gender inequality: Entrepreneurship development in the MENA region. Sustainability 2019, 11, 6472. [CrossRef]

21. UNDP. 2015 Human Development Report_Rethinking Work for Human Development; UNDP: Lake Success, NY, USA, 2015.

22. World Bank Group. Gender Equality, Poverty Reduction, and Inclusive Growth 2016-2023 Gender Strategy. Available online: http:/ / documents.worldbank.org/curated/en/820851467992505410/World-Bank-Group-gender-strategy-FY16-23-genderequality-poverty-reduction-and-inclusive-growth (accessed on 29 March 2020).

23. Sadler-Smith, E.; Badger, B. Cognitive style, learning and innovation. Technol. Anal. Strateg. Manag. 1998, 10, 247-266. [CrossRef]

24. Kirton, M. Adaptors and innovators: A description and measure. J. Appl. Psychol. 1976, 61, 622-629. [CrossRef]

25. Kirton, M.J. Adaption-Innovation: In the Context of Diversity and Change; Routledge: Abingdon, UK, 2003 ; ISBN 0203695003.

26. Kirton, M.J. KAI Advanced Feedback Booklet; Occupational Research Centre: Hertfordshire, UK, 1998.

27. Sánchez, J.C.; Carballo, T.; Gutiérrez, A. El emprendedor desde una orientación cognitiva. Psicothema 2011, $23,433-438$.

28. Menold, J.; Jablokow, K.; Purzer, S.; Ferguson, D.M.; Ohland, M.W. A critical review of measures of innovativeness. In Proceedings of the ASEE Annual Conference and Exposition, Indianapolis, IN, USA, 15-18 June 2014; pp. 1-17.

29. Chan, D. Detection of differential item functioning on the Kirton adaption-innovation inventory using multiple-group mean and covariance structure analyses. Multivar. Behav. Res. 2000, 35, 169-199. [CrossRef] [PubMed]

30. Sim, E.R. A Comparison of Adaption-Innovation Styles Between Information Systems Majors And Computer Science Majors. J. Inf. Syst. Educ. 2002, 13, 29-36.

31. Xu, Y.; Tuttle, B. Adaption-innovation at work: A new measure of problem-solving styles. J. Appl. Manag. Account. Res. 2012, 10, 17.

32. Gerry, C.; Marques, C.S.; Nogueira, F. Tracking student entrepreneurial potential: Personal attributes and the propensity for business start-ups after graduation in a Portuguese university. Probl. Perspect. Manag. 2008, 6, 46-54.

33. Carland, J.W.; Hoy, F.; Boulton, W.R.; Carland, J.A.C. Differentiating Entrepreneurs from Small Business Owners: A Conceptualization. Acad. Manag. Rev. 1984, 9, 354. [CrossRef]

34. Doyle, W.; Fisher, R.; Young, J.D. Entrepreneurs: Relationships Between Cognitive Style and Entrepreneurial Drive. J. Small Bus. Entrep. 2002, 16, 2-20. [CrossRef]

35. Isaksen, S.G.; Puccio, G.J. Adaption-Innovation and the Torrance Tests of Creative Thinking: The Level-Style Issue Revisited. Psychol. Rep. 1988, 63, 659-670. [CrossRef] 
36. Chávez-Eakle, R.A.; Del Carmen Lara, M.; Cruz-Fuentes, C. Personality: A possible bridge between creativity and psychopathology? Creat. Res. J. 2006, 18, 27-38. [CrossRef]

37. Cromie, S. Assessing entrepreneurial inclinations: Some approaches and empirical evidence. Eur. J. Work Organ. Psychol. 2000, 9 , 7-30. [CrossRef]

38. Jaskyte, K.; Kisieliene, A. Determinants of employee creativity: A survey of Lithuanian nonprofit organizations. Voluntas 2006, 17, 128-136. [CrossRef]

39. Peterson, B.E.; Pang, J.S. Beyond politics: Authoritarianism and the pursuit of leisure. J. Soc. Psychol. 2006, 146, 443-461. [CrossRef] [PubMed]

40. Mayer, R.E. Fifty Years of Creativity Research. Handb. Creat. 2014, 449, 449-460. [CrossRef]

41. Miron-Sspektor, E.; Erez, M.; Naveh, E. The effect of conformist and attentive-to-detail members on team innovation: Reconciling the innovation paradox. Acad. Manag. J. 2011, 54, 740-760. [CrossRef]

42. Edmondson, A. Psychological safety and learning behavior in work teams. Adm. Sci. Q. 1999, 44, 350-383. [CrossRef]

43. Helson, R.; Pals, J.L. Creative potential, creative achievement, and personal growth. J. Pers. 2000, 68, 1-27. [CrossRef]

44. Hutchinson, L.R.; Skinner, N.F.; Road, C.; Kwang, N.A.; Perlini, A. Self-Awareness and Cognitive Style: Relationships among Adaption-Innovation. Soc. Behav. Pers. 2007, 35, 551-560. [CrossRef]

45. Gurel, E.; Altinay, L.; Daniele, R. Tourism students' entrepreneurial intentions. Ann. Tour. Res. 2010, 37, 646-669. [CrossRef]

46. Gürol, Y.; Atsan, N. Entrepreneurial characteristics amongst university students. Educ. Train. 2006, 48, 25-38. [CrossRef]

47. Zani, R.M.; Sabir Ahmad, S.; Zakaria, A. The Predictors of Entrepreneurial Intention among Undergraduate Students. $e$-Acad. J. 2016, 5, 148-158.

48. Frese, M.; Fay, D. 4. Personal initiative: An active performance concept for work in the 21st century. Res. Organ. Behav. 2001, 23, 133-187. [CrossRef]

49. Zhao, H.; Hills, G.E.; Seibert, S.E. The mediating role of self-efficacy in the development of entrepreneurial intentions. J. Appl. Psychol. 2005, 90, 1265-1272. [CrossRef] [PubMed]

50. Wilson, F.; Kickul, J.; Marlino, D. Gender, entrepreneurial self-efficacy, and entrepreneurial career intentions: Implications for entrepreneurship education. Entrep. Theory Pract. 2007, 31, 387-406. [CrossRef]

51. Krueger Jr, N.F.; Brazeal, D. V Entrepreneurial potential and potential entrepreneurs. Entrep. Theory Pract. 1994, 18, 91-104. [CrossRef]

52. Ramo, P.; Veland, R.; Paul, D.L. Entrepreneurship in Bosnia and Herzegovina: Focus on gender. Eur. Bus. Rev. 2017, 29, 476-496. [CrossRef]

53. Veljkovic, S.; Marić, M.; Subotic, M.; Dudic, B.A.Z.; Greguš, M. Family Entrepreneurship and Personal Career Preferences as the Factors of Differences in the Development of Entrepreneurial Potential of Students. Sustainability 2019, 11, 5693. [CrossRef]

54. Gracanin, A.; Coso, B. Evaluation of the programme for the development of the entrepreneurial competences of the young. Napredak 2013, 154, 401-425. 